\title{
A rare mechanism of ectopy
}

\author{
D. Wesselius $\cdot$ J. Constandse $\cdot$ A. D. Hauer
}

Published online: 11 May 2020

(c) The Author(s) 2020

\section{Answer}

The electrocardiogram (ECG) shows a sinus rhythm at $80 \mathrm{bpm}$ with three broad ( $140 \mathrm{~ms}$ ) QRS complexes with a right bundle branch block (RBBB) morphology and inferior axis (Fig. 1). The first two broad QRS complexes show an initial $\mathrm{q}$ wave in lead V1, indicating a ventricular origin of the broad QRS complexes with a morphology compatible with a focus in the left ventricular summit. RBBB aberrancy is very unlikely since the septal activation should not change during $\mathrm{RBBB}$ aberrancy and should therefore not lead to a $q$ wave in lead V1. The third premature ventricular complex (PVC) is slightly shorter ( $120 \mathrm{~ms}$ ) and an initial q wave is absent illustrating fusion of the PVC with the intrinsic rhythm. There are irregular coupling intervals of PVCs with the preceding QRS complexes. In addition, the interval between the first two PVCs (3760 ms) exactly doubles the interval between the last two PVCs (1880 ms) pointing to a common denominator of the intervals between the PVCs. These findings indicate an ectopic discharging focus, which is not influenced (no reset) by the intrinsic depolarisation, illustrating entrance block. However, activation originating in the ectopic focus is able to propagate to the surrounding tissue that is no longer refractory (absence of exit block). No PVC is observed at half the interval between the first and second PVC because the tissue sur-

rounding the ectopic focus is refractory due to depolarisation by the intrinsic rhythm. This mechanism of arrhythmia is called ventricular parasystole and generally has a benign clinical course ${ }^{1}$. Although the patient had mild complaints of palpitations, he refused medication or catheter ablation and preferred regular follow-up of left ventricular ejection fraction.

Open Access This article is licensed under a Creative Commons Attribution 4.0 International License, which permits use, sharing, adaptation, distribution and reproduction in any medium or format, as long as you give appropriate credit to the original author(s) and the source, provide a link to the Creative Commons licence, and indicate if changes were made. The images or other third party material in this article are included in the article's Creative Commons licence, unless indicated otherwise in a credit line to the material. If material is not included in the article's Creative Commons licence and your intended use is not permitted by statutory regulation or exceeds the permitted use, you will need to obtain permission directly from the copyright holder. To view a copy of this licence, visit http://creativecommons.org/licenses/by/4.0/.

\section{References}

\section{Further Reading}

1. Issa ZF, Miller JM, Zipes DP. Electrophysiological mechanisms of cardiac arrhythmias. In: Clinical arrhythmology and electrophysiology: A companion to Braunwald's heart disease. Philadelphia: Saunders;2012.p. 41.

D. Wesselius · A. D. Hauer $(\bowtie)$

Haga Teaching Hospital, the Hague, The Netherlands

a.hauer@rdgg.nl

J. Constandse $\cdot$ A. D. Hauer

Reinier de Graaf Ziekenhuis, Delft, The Netherlands 


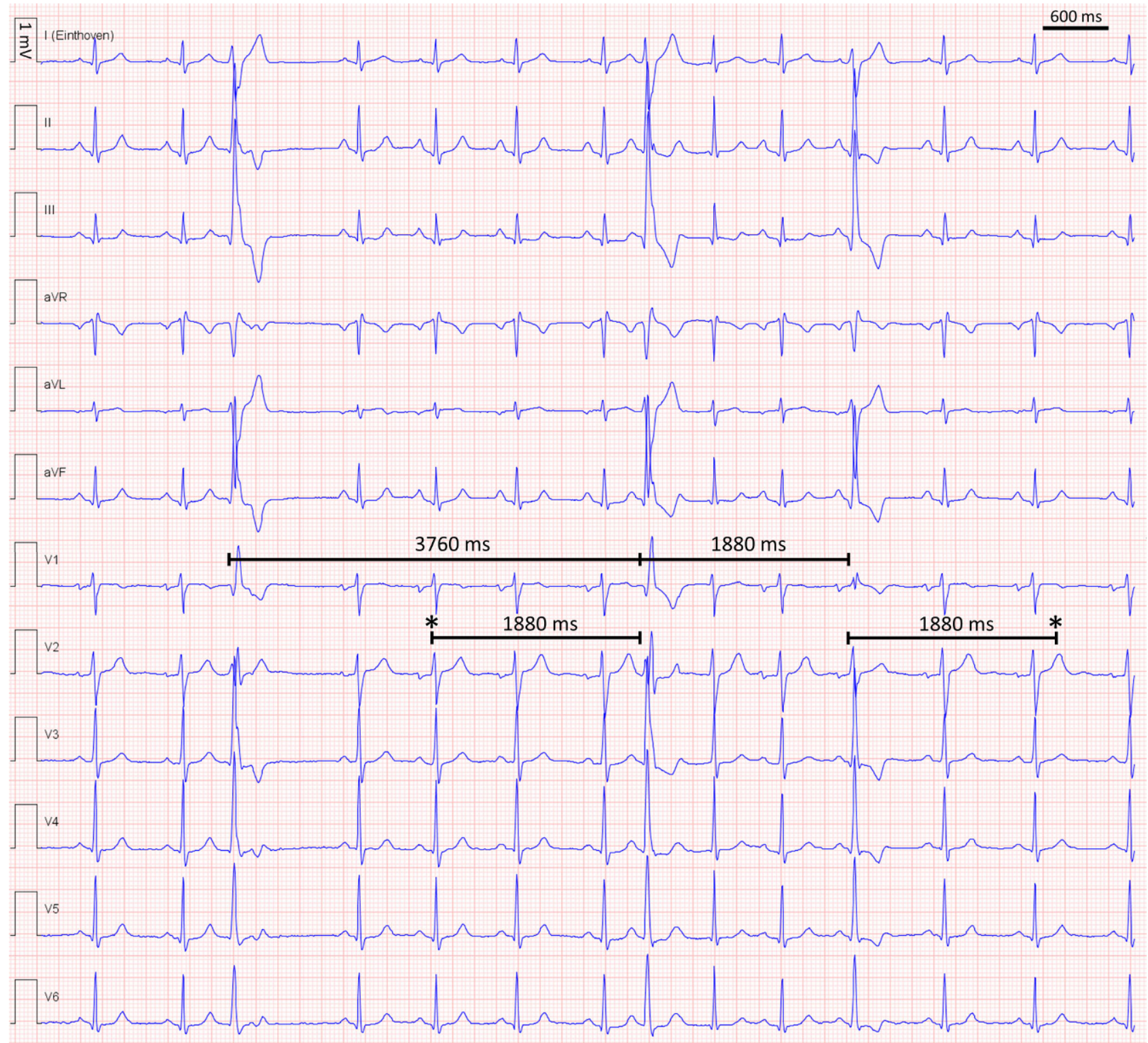

Fig. 1 12-lead electrocardiogram showing 3 premature ventricular complexes (PVCs) with irregular coupling intervals with the preceding QRS complexes and intervals between the PVCs with a common denominator $(1880 \mathrm{~ms})$. Asterisk Illus- trates expected timing of discharge of the ectopic ventricular focus which can not be propagated to the surrounding tissue because this tissue is refractory due to depolarisation by the intrinsic rhythm 